\title{
ТЕОРЕТИЧНІ ЗАСАДИ ДІЯЛЬНОСТІ РОЗВІДУВАЛЬНИХ СЛУЖБ КРАЇН ЄВРОПЕЙСЬКОГО СОЮЗУ В КОНТЕКТІ КОНЦЕПЦІЇ ЕПІСТЕМІЧНОї СПІЛЬНОТИ
}

Бурба В. В.

у статті висвітлено теоретичні проблеми діяльності розвідувального співтовариства Європейського Союзу. Виходячи із заявленого стратегічного курсу ЄС на створення європейського розвідувального співтовариства, автором пропонується з метою більш повного аналізу теоретичних основ побудови чієї інституції доповнити наявний методологічний інструментарій дослідження наднаціональних європейських структур новим підходом, в основу якого покладено епістемічну концепцію. Автор стверджує, що більшість інтеграційних процесів ЄС у сфері розвідки носять гібридний характер, що дає можливість забезпечувати ефективне співробітництво через поєднання тимчасових ситуаційних угод зі стабільними інституалізованими структурами. На основі проведеного аналізу робиться висновок, що розвідувальне співтовариство країн Європейського Союзу можна вважати своєрідною епістемічною спільнотою, однак її структура, організація і внутрішня логіка $\epsilon$ дуже специфічними та пристосованими одночасно до політичних і безпекових потреб країн-учасниць.

Ключові слова: розвідувальна діяльність, національні інтереси, міжнародні відносини, інформація, безпека.

В статье рассмотрены теоретические проблемы деятельности разведывательного сообщества Европейского Союза. Исходя из заявленного стратегического курса ЕC на создание европейского разведывательного сообщества, автором предлагается с целью более полного анализа теоретических основ построения этого института дополнить имеющийся методологический инструментарий исследования наднациональных европейских структур новым подходом, в основу которого положена эпистемическая концепция. Автор утверждает, что большинство интеграционных процессов ЕС в сфере разведки носят гибридный характер, что дает возможность обеспечивать эффективное сотрудничество посредством сочетания временных ситуационных соглашений со стабильными институализироваными структурами. На основе проведенного анализа делается вывод, что разведывательное сообщество стран Европейского Союза можно считать своеобразным эпистемичным сообществом, однако его структура, организация и внутренняя логика очень специфичны и приспособлены одновременно к политике и безопасности стран-участниц.

Ключевые слова: разведывательная деятельность, национальные интересы, международные отношения, информация, безопасность.

The implementation of Ukraine's European integration course in the context of Russian hybrid aggression requires a significant intensification of the activities of all subjects of national security. Ukraine's national security and defense legislation has, over the past few years, come much closer to the relevant legal norms of developed countries. While defining the principles that underpin the development of the security and defense sector for

Бурба В. В., 2019 integration into European and Euro-Atlantic security structures, Ukraine proceeds from the assumption that the development and strengthening of the EU and NATO deepens pan-European and international security in all its dimensions and requires appropriate democratic transformations of national security institutions. The concept of development of the security and defense sector of Ukraine stipulates that for the effective development of the security and defense sector in modern conditions it is necessary to: improve the system of state forecasting and strategic planning, the system of planning the use of troops (forces) and means of the security and defense sector on the basis of principles and EU and NATO standards. The intelligence community serves as a powerful component of the national security system of Ukraine, since it is intelligence services that can simultaneously solve a number of complex multi-vector problems. The article deals with the theoretical problems of the activities of the European Union intelligence community. Based on the stated strategic course of the EU for the creation of a European intelligence community, the author proposes to supplement the existing methodological toolkit for the study of supranational European structures with a new approach, based on an epistemic concept. The author argues that most of the EU integration processes in the field of intelligence are hybrid in nature, which makes it possible to ensure effective cooperation through a combination of temporary situational agreements with stable institutionalized structures. Based on the analysis, it is concluded that the intelligence community of the European Union countries can be considered a kind of epistemic community, but its structure, organization and internal logic are very specific and adapted simultaneously to the politics and security of the participating countries.

Key words: intelligence, national interests, international relations, information, security.

Постановка проблеми. Реалізація євроінтеграційного курсу України в умовах російської гібридної агресії вимагає значної активізації діяльності всіх суб'єктів забезпечення національної безпеки. Законодавство 3 питань національної безпеки і оборони України протягом останніх декількох років значно наблизилося до відповідних правових норм розвинених країн. Визначаючи принципи, що закладені в основу розвитку сектору безпеки і оборони щодо інтеграції до європейських та євроатлантичних безпекових структур, Україна виходить із того, що розвиток і зміцнення ЄС та НАТО поглиблюють загальноєвропейську та міжнародну безпеку в усіх іï вимірах та вимагають проведення відповідних демократичних перетворень національних безпекових інституцій. Концепцією розвитку сектору безпеки і оборони України [1] передбачається, що для ефективного розвитку сектору безпеки і оборони в сучасних умовах необхідно: вдосконалення системи державного прогнозування та стратегічного планування, системи планування застосування військ (сил) і засобів сектору безпеки і оборони на основі принципів і стандартів $\in C$ 
та НАТО. Розвідувальне співтовариство виконує роль потужної складової частини системи захисту національної безпеки України, оскільки саме розвідувальні служби у змозі одночасно вирішувати ряд складних різновекторних завдань.

Вивчення досвіду теоретичних засад діяльності розвідувальних служб країн Європейського Союзу набуває винятково важливого значення не лише в аспекті повноцінної участі нашої держави у функціонуванні безпекових європейських інституцій, але й з огляду на те, що країни Європейського Союзу протягом останніх років суттєво змінюють підходи до регулювання діяльності розвідувальних служб. Наразі спостерігаються чіткі тенденції до розмежування на норми, правила та стандарти, що стають обов'язковими для організації діяльності розвідувальних служб усіх членів європейської спільноти, та національне спеціальне законодавство, яке притаманне кожній країні ЄС. Окрім того, в даному контексті актуальним $€$ вивчення організації розвідувальної діяльності в Європейському Союзі з огляду на те, що лише однієї імплементації законодавства $€ C$ із питань регулювання діяльності розвідувальних служб в законодавчу практику України недостатньо для реального підвищення якості роботи розвідувального співтовариства.

Наведене дає підстави дослідження теоретичних основ діяльності розвідувальних служб країн $Є С$ та можливостей застосування їх досвіду в роботі розвідувального співтовариства України в якості актуальної проблеми, що має важливе значення для юридичної науки і практики.

Аналіз останніх досліджень і публікацій, в яких започатковано розв'язання проблеми. Окремі питання вивчення та використання європейського досвіду організації діяльності розвідувальних служб тією чи іншою мірою висвітлювалися в наукових працях українських та іноземних учених.

Так, у монографічному дослідженні В. Гвоздя висвітленню побудови розвідувальних служб провідних країн світу присвячено окремий розділ. Зокрема, автором зазначається, що утворені на державному рівні спеціальні служби можна зарахувати до специфічного виду зброї, налаштованої на розгром супротивника навіть за мирних умов, коли гармати ще мовчать. Баланс між потребою розвідувальних служб у правових стандартах, що створюють сприятливі умови для збору і добування ними розвідувальної інформації, і необхідністю захисту конституційних прав і свобод громадян певною мірою $\epsilon$ умовно-історичною категорією, яка застосовується лише до конкретного історичного етапу розвитку держави і суспільства. Цей баланс змінюється із часом і під впливом історичних обставин, породжуючи або дуже жорсткі обмежувальні стандарти, що регулюють діяльність розвідки, або стандарти, що вкрай розширюють іiі права і можливості [2, с. 207].

У Резюме Інформаційної довідки, підготовленої Європейським інформаційно-дослідницьким центром, підкреслюється, що для розвідувальних служб наведених країн характерним $\epsilon$ поділ на цивільні та військові органи розвідки з різним рівнем співпраці та координації їхньої діяльності центральними органами виконавчої влади. Для цивільних органів розвідки характерним $є$ підзвітність та підконтрольність Уряду, Президенту та Парламенту. У ряді країн, таких як Чехія, Естонія, Польща, Румунія, Велика Британія, Німеччина, США, окремо працює служба зовнішньої та внутрішньої розвідки. Для цивільних служб розвідки характерним $\epsilon$ урядове підпорядкування. Для розвідок США, Великобританії, Німеччини, Чехії та Естонії характерним $\epsilon$ наявність центральних координаційних органів. У Німеччині - це федеральна служба розвідки, що входить до компетенції федерального Канцлера Німеччини. У Великобританії - Об'єднаний розвідувальний комітет, що підпорядковується Уряду. В урядовому підпорядкуванні також знаходяться Комітет розвідувальної діяльності Чеської республіки та Урядова комісія з національної безпеки Естонії [3, с. 27].

Досить слушною видається позиція А. Мартинова, який констатує незавершеність процесу оформлення дипломатичної служби ЄС, що засвідчують проблеми оформлення розвідувального співтовариства Європейського Союзу. Автор підкреслює, що побудова відповідних вертикальних розвідувальних структур вимагатиме створення спеціалізованого європейського розвідувального агентства, яке візьме на себе аналітичні функції та стане центром збирання інформації від національних спеціальних служб. Однак поки що незрозуміло, як це кореспондуватиметься з розвідувальними структурами НАТО, і незрозуміло, як фінансувати цю діяльність. Натомість горизонтальна координація сприяє побудові мережі, за допомогою якої спрощується процедура встановлення як двосторонніх, так і багатосторонніх контактів для обміну розвідувальною інформацією. Зрозуміло, що це вимагатиме інституціоналізації відносин між учасниками. Поки що розвідувальне співтовариство Європейського Союзу представлене сукупністю розвідувальних співтовариств країн-членів Європейського Союзу. Від них залежить, наскільки Європа просунеться шляхом створення єдиної наднаціональної розвідувальної служби [4с. 46].

Р. Марутян, досліджуючи можливості участі України у формуванні нового європейського безпекового простору, зазначає, що НАТО сьогодні не забезпечує повною мірою гарантій безпеки європейцям, і тому в реформуванні оборонної сфери вже було зроблено певні практичні кроки. Так, Ж.-К. Юнкер у вересні 2017 р. під час виступу в Європарламенті заявив про створення до 2025 р. Європейського оборонного союзу, що існуватиме паралельно і в партнерстві з НАТО. Це зможе дозволити для ЄС самостійно діяти в операціях за кордоном для стабілізації сусіднього простору і посилення своєї ролі як гаранта безпеки. Крім того, резолюція Європарламенту пропонувала заснувати Головне управління з питань оборони, яке б на рівні $€ С$ відповідало за внутрішні аспекти політики оборони і безпеки, а також створити Європейський розвідувальний відділ [5].

І. Копотун, висвітлюючи конституційні засади діяльності розвідувальних органів України, наголошує, що вимоги стандартів ЄC щодо розвідувальних органів стосуються таких основних аспектів, як контроль над цими органами, відповідність їх діяльності, Конституції та законами України, їх підзвітність. Україна, яка прагне в майбутньому набути членства у Європейському Союзі, взяла на себе зобов'язання щодо приведення національного законодавства у відповідність до європейських стандартів із дотриманням, у тому числі, рекомендацій, які надходять від європейських структур. Автор на основі проведеного аналізу відповідності окремих положень Конституції України положенням чинного законодавства стосовно організації та діяльності розвідувальних органів України пропонує в подаль- 
шому вдосконалити наявну законодавчу базу, точніше відобразити у правових нормах демократичні принципи Основного Закону України [6].

О. Романенко, висвітлюючи роль епістемічних спільнот в інформаційно-аналітичній діяльності, зазначає, що епістемічні спільноти стають важливим і видимим актором у системах державного та суспільного управління. Вони являють собою національні та наднаціональні політико-академічні комплекси, здатні за допомогою проведення високоякісних, прогресивних досліджень, а також шляхом подальшого практичного втілення їх результатів виступати інструментом управління ключовими політичними, економічними, гуманітарними процесами. Роль даних груп особливо зростає в моменти політичної невизначеності або кризи. У такі періоди вони здатні об'єктивно роз'яснити ситуацію, запропонувати варіанти розвитку подій, попередити осіб, які приймають стратегічні державні рішення, про можливі помилки. Епістемічні спільноти зазвичай не працюють «на замовлення»; навпаки, володіючи суб'єктністю, вони здатні самостійно встановлювати і вирішувати найважливіші проблеми [7].

Таким чином, проведений аналіз останніх наукових досліджень за заявленою тематикою засвідчив необхідність наукового аналізу теоретичних засад діяльності розвідувальних служб країн Європейського Союзу як виду епістемічної спільноти, зокрема в контексті визначення євроінтеграційного безпекового курсу України.

Формулювання цілей статті - аналіз інституціонального забезпечення діяльності розвідувальних служб країн Європейського Союзу в епістемічному концепті та уточнення на цій основі теоретико-методологічних та науково-прикладних засад його дослідження.

Результати дослідження. Розвідувальна діяльність, як один із найважливіших елементів системи забезпечення колективної безпеки $Є С$, розвивається в певному інституційному та функціональному контексті відповідно до загальних цілей європейської інтеграції. Глобалізаційні процеси зумовлюють актуалізацію нових викликів і загроз людському розвиткові, що актуалізує необхідність модернізації підходів спеціальних служб до добування розвідувальної інформації (джерела інформації все частіше знаходяться за кордоном, поза межами юрисдикції та формальної компетенції тієї чи іншої держави). Отримання інформації від такого роду конфідентів вимагає досягнення міжнародних, офіційних або неформальних угод чи домовленостей.

Ідея обміну розвідувальними даними між країнами-членами $€$ отримала свій розвиток на початку 1990-х рр. У той час були оформлені інституційні рамки для ведення розвідувальної діяльності в інтересах усього Євросоюзу. Їх еволюція в наступні роки була тісно пов'язана із прийняттям у 1999 р. Європейської безпекової та оборонної політики (ЄБОП), а також створенням організаційних структур, відповідальних за забезпечення керівництва ЄС інформацією, необхідною у процесі прийняття рішень при впровадженні ЄБОП. Із розвитком Євросоюзу змінювались і структури, відповідальні за інформаційну підтримку реалізації як ЄБОП (з 2010 р. - Спільна безпекова та оборонна політика - СБОП), так і Європейської служби зовнішньої діяльності (ЄСЗД), створеної у 2009 р. Сьогодні $Є С$ у рамках СБОП має у своєму розпорядженні: Військовий штаб, який складається 3 військовослужбовців країн-членів Євросоюзу i, в основному, відпо- відає за проведення військових операцій у кризових ситуаціях; Супутниковий центр, дислокований в Іспанії; Інститут досліджень проблем безпеки, розташований у Парижі. Однак ключовою установою у цій сфері $\epsilon$ Розвідувальний і ситуаційний центр (РСЦ), який почав функціонувати у 2002 р. (до 2012 р. мав назву Ситуаційний центр). 32011 р. він входить до складу ЄСЗД і підпорядковується безпосередньо Верховному представнику Євросоюзу в закордонних справах і безпекової політики [8].

Як слідує з останніх публікацій офіційних інформаційних джерел $Є С$, стратегічним вектором розвитку безпекового простору Європейського Союзу на сьогодні стало визначення функціональної структури взаємопов'язаних розвідувальних інституцій окремих країн. Для досягнення цієї мети держави-члени, разом із відповідними агенціями ЄС, працюють над створенням європейського розвідувального співтовариства, що ґрунтується на ефективному обміні розвідувальною інформацією, важливою з точки зору фактору часу, обміну кращими практиками та аналітичними даними. Так, у березні 2019 року відбулося перше дводенне засідання нещодавно створеної Колегії європейської розвідки - особливого органу, який дозволить високопоставленим співробітникам спецслужб обмінюватися досвідом і обговорювати загальну стратегію. Колегія має стати місцем розвитку дипломатичних зв'язків, обміну думками та діалогу для представників європейських спецслужб, а також для академічного світу та наукових досліджень. При цьому безпосередня діяльність розвідувальних служб європейських країн залишається національною прерогативою. Під час таких конференцій, які проводитимуться чотири рази на рік, представники спецслужб не будуть обмінюватися особливо чутливими відомостями - спецслужби часто не готові ділитися між собою даними, які стосуються, зокрема, контррозвідки або економічних злочинів. Про наміри створити спеціальну організацію, яка б координувала європейські спецслужби, було оголошено у вересні 2017 р. (мова йшла про заснування «Академії європейської розвідки», яка не повинна займатися навчанням співробітників розвідувальних відомств).

Виходячи з основ інституціональної теорії, розвідувальне співтовариство можна представити у вигляді своєрідних інститутів, основним призначенням яких виступає розвідувальна діяльність в інтересах державного органу, наділеного владними повноваженнями у сфері забезпечення національної безпеки. Поширення впливу розвідувального співтовариства на міждержавний рівень інформаційного співробітництва повинне узгоджуватися з базовими принципами міжнародного співробітництва у сфері розвідки. Основний із них вважається позитивним - він відображає конструктивні відносини між партнерами, засновані на спільних цінностях, цілях та інтересах. Взагалі співпраця між спецслужбами вважається нормальним явищем, оскільки в більшості випадків вона характеризується досить високою ефективністю та відповідає національним інтересам країн, які вони представляють. Разом із цим існує й негативний аспект, що полягає в невизначеності небезпек і загроз, що стимулюють необхідність обміну розвідувальними даними в довготерміновій перспективі. Також можлива зміна розвідувальних пріоритетів у зв'язку із внутрішньополітичними процесами, які відбуваються в окремих країнах. 
Як засвідчили результати аналізу інтеграційних процесів ЄС у сфері розвідки, більшість із них сьогодні носять гібридний характер, що дає змогу забезпечувати ефективну та надійну структуру співробітництва шляхом поєднання тимчасових ситуаційних домовленостей зі стабільними інституалізованими структурами. Стійкість даних структур забезпечується безальтернативним домінуванням принципу національного суверенітету в міждержавних відносинах. Критерії необхідності спільного реагування розвідувальних служб країн $Є С$ на виклики та загрози встановлюються через поєднання цілей і заходів забезпечення національної безпеки окремих країн-учасниць та спільних інституційних спроможностей міждержавних безпекових структур. Наведене підкреслює наявність специфічних характеристик, які властиві розвідувальному співтовариству на рівні Європейського Союзу.

Найбільш розповсюдженим методологічним інструментарієм дослідження феномену транскордонного співробітництва в Європейському Союзі сьогодні виступає поєднання таких теоретико-методологічних підходів: політичного - розглядає транскордонне співробітництво як метод реалізації політичних інтересів держави; реалістичного - зводить транскордонне співробітництво до міждержавних взаємодій на основі політичних принципів взаємного визнання, суверенітету та невтручання у внутрішні справи один одного; регіонального - акцентує на наявності кордонів та передбачає їх просторове подолання; підхід «конфлікт-співробітництво» ставить транскордонне співробітництво на другий план порівняно 3 дослідженнями, присвяченими аналізу цих двох явищ; соціологічний передбачає існування транскордонних контактів у тісному зв'язку з культурними, етнічними цінностями [9, с. 20].

Наведені підходи не у змозі повністю розкрити особливості теоретичних засад співробітництва країн Європейського Союзу в розвідувальній сфері, тому їх необхідно доповнити методами, в основу яких покладено концепцію епістемічних спільнот. Запропонована новела надає нові можливості висвітлення особливостей діяльності розвідувального співтовариства на рівні $€ С$ через призму епістемічної теорії.

Епістемічні спільноти - це мережа професіоналів, які володіють високим рівнем знань у певній сфері, визнаною компетенцією та авторитетом, а також бажанням втілити свої знання у вигляді конкретної державної програми. Основними їх ознаками $\epsilon$ такі: універсальний комплекс норм та вірувань, які забезпечують ціннісно-орієнтоване обґрунтування соціальної активності членів групи; спільне розуміння проблеми, яке виникає в результаті дослідження центрального комплексу питань і яке виступає основою для поєднання певних практичних дій із бажаними результатами; беззастережне прагнення до достовірності - тобто міжсуб'єктних, внутрішньо визначених критеріїв для оцінки знань; колективне просування рішень - система практичних дій, необхідних для реалізації знань, кінцевим результатом якої має стати покращення життя соціуму [10].

Епістемічну спільноту розглядають також як мережу експертів-аналітиків, які володіють привілейованим доступом до інформації та спеціальних знань, необхідних для оптимізації процесу прийняття рішень [11, с. 116]. Суспільні та політичні інституції повністю довіряють та покладаються на висновки провідних фахівців, оскільки вони користуються не лише загаль- нодоступними джерелами інформації, але й конфіденційними даними й відомостями. У даному аспекті епістемічна спільнота передбачає у своєму складі наявність лише висококваліфікованих фахівців, які наділені особливими аналітичними можливостями та досвідом. Роль цієї спільноти зводиться до забезпечення посадових осіб обробленою максимально точною інформацією, що лягає в основу прийняття особливо важливих рішень. Тому епістемічні спільноти не можуть керуватися здогадками чи покладатися на неточну інформацію - вона повинна формуватися з різних джерел і відображати узагальнену картину суджень, інтерпретацій та альтернатив щодо розвитку політичних чи соціально-економічних процесів.

У класичній концептуалізації епістемічні спільноти трактуються в якості вертикально орієнтованих гетерогенних інституціоналізованих мереж, що формуються з метою впливу на структури державного управління. Наведене визначення містить досить важливе обмеження: цей вид спільнот виникає та функціонує поза сферою політичних рішень - вони можуть стимулювати дебати, формувати альтернативи, однак вони не беруть безпосередньої участі у виборчих процесах та не несуть політичної відповідальності [12, с. 235]. У даному аспекті епістемічні спільноти характеризуються тим, що вони належать до середовища прийняття рішень, однак приймати самостійно вони їх не можуть. Наведене зумовлює неможливість членства політичних діячів та громадських активістів в епістемічних спільнотах (їх політична заангажованість та уподобання не відповідають потребам неупередженого аналізу) [13, с. 18].

Взагалі роль епістемічних груп у Європейському Союзі розглядається вченими в якості специфічного інструменту посилення безпосередньої участі громадян у публічній політиці. Такого роду структури у змозі ефективно подолати так звану «проблему демократичного дефіциту». Для цього вони можуть використовувати ряд методів: від порушення громадських дискусій у країнах - членах Союзу й актуалізації окремих суспільно-важливих проблем і аж до безпосереднього впливу на політичних лідерів шляхом вироблення висококваліфікованих, науково обґрунтованих стратегій [14]. Так, наприклад, представниками дипломатичного корпусу країн-членів ЄС організовано досить впливову організацію - Комітет постійних представників, який можна вважати класичною епістемічною спільнотою. Саме тут формується порядок денний, здійснюється безперервний моніторинг та створюється аналітичний продукт, що втілюється у практичну площину шляхом ухвалення рішень Радою міністрів ЄС. Окрім того, Комітет виступає форумом для діалогу та ареною для обміну думками тощо [15].

Із практичної точки зору епістемологічні спільноти можуть сприйматися в якості консультативної інституції, основним завданням якої виступає аналіз міжнародної політики, та міждержавних відносин із метою інформування посадовців, які приймають важливі рішення [16]. Так, на переконання П. Хааса, епістемічна спільнота завжди несе відповідальність за правильне визначення рівня реальних загроз національній безпеці та вибір адекватної політики їх нейтралізації. Він же стверджує, що епістемічні співтовариства можуть виробляти нові політичні альтернативи для прийняття відповідальних рішень національними урядами, однак вони можуть і переслідуватися за свої переконання всередині країни [17]. 
Серед основних чинників, що впливають на діяльність епістемічних груп, виділяються такі: у стратегічних відносинах між державами очікування від взаємодії формуються завдяки розумінню теорії взаємозв'язків між причинами та наслідками того чи іншого явища; якщо не існує попереднього досвіду щодо вирішення проблеми, то відповідна теорія базується на узагальнених та абстрактних моделях; характер такого роду теорій зумовлює їх науковий розвиток та передачу на політичний рівень через авторитетні академічні кола; передача теоретичних розробок може носити формальний чи неформальний характер, що дає можливість розробити спільні стратегії вирішення проблеми; використання наукових методів дисциплінує поведінку посадових осіб, примушуючи їх дотримуватися епістемічних рамок; розвиток міжнародного співробітництва залежить від раціональності прийнятих рішень політичними лідерами [18, с. 101].

Висновки. Таким чином, розвідувальне співтовариство країн Європейського Союзу виступає своєрідною епістемічною спільнотою, однак іï структура, організація і внутрішня логіка $\epsilon$ дуже специфічними та пристосованими одночасно до політичних і безпекових потреб. Тому його можна вважати не класичною, а дещо видозміненою епістемічною структурою, насамперед, виходячи з унікальних можливостей щодо обробки та аналізу інформації з різнорідних джерел (у тому числі й таких, що носять таємний характер), а також відсутності єдиного управлінського органу (наявні на сьогодні структури носять переважно консультативний характер). Видозмінена епістемічна спільнота містить в основі лише горизонтальні зв'язки між різними зацікавленими сторонами, включаючи уряди, приватні організації та наднаціональні суб'єкти. Її основне завдання полягає в інтеграції розрізнених джерел інформації з метою іï доведення до зацікавлених інституцій. Така модель епістемічнго співтовариства не лише сприяє більш ефективній діяльності національних розвідувальних структур, але й дає можливість компенсувати слабкі сторони міжнародної співпраці у цій сфері. Ураховуючи, що співпраця розвідувальних структур досить істотно залежить від політичних чинників та підпорядкована стратегічним орієнтирам забезпечення національної безпеки кожної країни ЄС, епістемічне співтовариство вимушене брати безпосередню участь у виробленні спільної безпекової політики Європейського Союзу. Разом із цим постійний дефіцит важливої інформації, іï невизначеність, а також складні механізми вироблення рішень на міжнародному рівні породжують постійні виклики для учасників розвідувального співтовариства, іноді призводячи до серйозних деформацій структурних та інституційних засад співробітництва у цій сфері. Гібридна структура видозміненої епістемічної спільноти, що охоплює як гетерогенні, так і гомогенні взаємодіючі компоненти, носить не лише позитивний характер (оперативність в обміні інформацією), але й негативний (залежність від впливу політичних чинників, що призводить до неефективного та менш гнучкого реагування на загрози безпеці європейської спільноти).

\section{Література}

1. Указ Президента України від 14.03.2016 p. № 92/2016 «Про рішення Ради національної безпеки і оборони України від 4 березня 2016 року «Про Концепцію розвитку сектору безпеки і оборони України». URL : https://zakon.rada.gov.ua/laws/show/ru/92/2016\#n2.

2. Гвоздь В.І. Історичні, правові і політичні аспекти розвідувальної діяльності держави. Київ : «Борисфен Інтел», 2018. 576 с.

3. Особливості діяльності розвідувальних служб країн Європейського Союзу та США Інформаційна довідка, підготовлена Європейським інформаційно-дослідницьким центром на запит народного депутата України. URL : http: / / euinfocenter.rada.gov.ua/uploads/documents / 28833.pdf.

4. Мартинов, А. (2015). Спільна зовнішня і безпекова політика Європейського Союзу: основні етапи розвитку. Європейські історичні студії. 2015. № 1. С. 43-61.

5. Марутян P. PESCO - новий європейський оборонний союз: можливості для України. URL : http://matrix-info. com/2018/01/13/pesco-novyj-yevropejskyj-oboronnyjsoyuzmozhlyvosti-dlya-ukrayiny/.

6. Копотун І. Конституційні засади діяльності розвідувальних органів України. Сучасна кримінологія: досягнення, проблеми, перспективи. Харків: Право, 2016. 236 с.

7. Романенко О. Роль епістемічних спільнот в інформаційно-аналітичній діяльності. URL : http://en.chnu.edu. ua/wp-content/uploads/2018/03/Romanenko-1.pdf.

8. Паливода В. Чи вдасться Європейському Союзу об'єднати розвідувальні зусилля? URL: http: / /opk.com.ua/.

9. Краснейчук А. Теоретико-методологічні засади розвитку транскордонного співробітництва. Вісник Національної академії державного управління при Президентові України. 2014. № 3. С. 18-27.

10. Haas P. Introduction: epistemic communities and international policy coordination. International Organization. 1992. 46(01). P. 1.

11. Malloy T. David J. Galbreath and Joanne McEvoy, The European Minority Rights Regime. Towards a Theory of Regime Effectiveness, Houndmills, Palgrave, 2012, 209 pp, Security and Human Rights. 2013. 24(1). pp.115-117.

12. Sebenius J. Challenging conventional explanations of international cooperation: negotiation analysis and the case of epistemic communities. International Organization. 1992. 46(01). P. 323.

13. Mintz A., DeRouen K., Jr. Understanding foreign policy decision making. Cambridge: CambridgeUniversity Press, 2010.

14. Howorth J. Discourse, Ideas, and Epistemic Communities in European Security and Defence Policy. West European Politics. 2004. 27(2). P. 211-234.

15. Shore C. European Governance or Governmentality? The European Commission and the Future of Democratic Government. European Law Journal. 2011. 17(3). Pp. 287-303.

16. Haas P. and Haas $G$. The prevalence of hemorrhoids and chronic constipation. Gastroenterology. 1990. 99(6). Pp.1856-1857.

17. Haas P. Banning chlorofluorocarbons: epistemic community efforts to protect stratospheric ozone. International Organization. 1992. 46(01). P. 187.

18. Adler $\mathrm{E}$. The emergence of cooperation: national epistemic communities and the international evolution of the idea of nuclear arms control. International Organization. 1992. 46(01). P. 101.

Бурба В. В., кандидат юридичних наук, доцент, професор CK-4

Навчально-наукового інституту перепідготовки та підвищення кваліфікації кадрів Служби безпеки України 